\title{
Bidirectional mass selection for body shape in common carp
}

\author{
Y Ankorion, R Moav ${ }^{\dagger}, \mathrm{GW}$ Wohlfarth * \\ Agricultural Research Organization, Fish and Aquaculture Research Station, \\ Dor, DN Hof Hacarmel 30820, Israel
}

(Received 27 November 1990; accepted 19 November 1991)

\begin{abstract}
Summary - Bidirectional mass selection for the ratio of height/length generated a response in both directions. Estimates of realized heritability were $0.47 \pm 0.06$ and $0.33 \pm 0.10$ for up and down selection respectively and $0.42 \pm 0.03$ for the divergence. This means that body shape of common carp can be changed fairly rapidly by mass selection. Presumably, differences in body shape among different genetic groups of common carp are due to different intensities and number of generations of mass selection for this trait practised in the past. The traditional belief that body shape and growth rate are correlated was not confirmed in this study. The down selection line, possessing the lowest ratio of height/length, showed the fastest growth rate. At face value this implies a negative correlated response of growth to selection for height/length. We suggest treating this finding with some reservation, since growth did not differ significantly among our test lines. These results may be applied to aquaculture by selecting for an increasing ratio of height/length only if high backed fish have some advantage in their own right such as a higher price or improved market acceptance.
\end{abstract}

common carp / body shape / realized heritability / bidirectional mass selection

Résumé - Sélection massale divergente pour la conformation chez la carpe commune. Une sélection massale divergente pour la conformation chez la carpe commune (rapport hauteur/longueur) a produit une réponse à la fois vers le haut et vers le bas. Les estimées de l'héritabilité réalisée après une génération de sélection sont $0,47 \pm 0,06$ et $0,33 \pm 0,10$ respectivement dans la lignée haute et dans la lignée basse, et $0,42 \pm 0,03$ pour la divergence entre les 2 lignées. Cela suggère que la conformation de la carpe commune peut être modifiée assez rapidement par sélection massale. Il est probable que les différences de conformation entre différents groupes génétiques de carpe sont le résultat d'une sélection pour ce caractère, effectuée avec des intensités et sur un nombre de générations variables selon les groupes. Cette étude ne confirme pas l'opinion courante selon laquelle la conformation et la vitesse de croissance sont corrélées : c'est en effet la

$\dagger$ Deceased

* Correspondence and reprints 
lignée basse, possédant le rapport hauteur/longueur le plus faible, qui manifeste la plus forte croissance. Ce résultat, qui impliquerait une corrélation négative entre croissance et conformation, doit cependant être interprété avec réserve, les différences de croissance entre les lignées expérimentales n'étant pas significatives. Compte tenu de ces résultats une sélection pour un rapport hauteur/longueur accru se justifie en aquaculture à condition que les poissons à conformation «ramassée» aient un avantage intrinsèque, tel que un meilleur prix de vente ou une meilleure acceptabilité.

carpe commune / conformation / héritabilité réalisée / sélection divergente

\section{INTRODUCTION}

In the traditional carp culture management in central and eastern Europe, body shape and particularly the ratio of height/length is regarded as important. This trait responds to environmental influences (Anwand, 1961; Mann, 1961) and distinguishing carp races by their body shape is considered unreliable. Nevertheless, among common European carp races, Aischgrund and Galician are regarded as relatively high backed, and Lausitz and Frankish as having a relatively elongated body shape (Willer, 1933; Hofmann, 1975). The traditional method of selecting brood stock at the time of harvesting 3-year old fish consisted of picking out the largest individuals with the highest ratio of height/length (Hofmann, 1975). This practice was based on the belief that the ratio of height/length is correlated to growth, and that both growth rate and body shape respond to mass selection. High backed carp are also considered more aesthetic, with a market preference in certain areas.

The paper presented here is based on a thesis of the senior author (Ankorion, 1966). One of the aims of this investigation was to study the inheritance of the ratio body height/body length, and its correlation with growth rate.

\section{MATERIALS AND METHODS}

The realized heritability of the ratio height/length was estimated in a bidirectional mass selection experiment. "Height" is here defined as the maximum height of the fish, measured from the anterior base of the dorsal fin to the anterior base of the pelvic fin. "Length" is standard length, measured from the snout to the base of the caudal fin. Selection was carried out in a commercial production pond at the fish farm of Gan Shmuel, on market sized fish (then about $500 \mathrm{~g}$ ). The pond was stocked with a sample of crossbred fry. The parents of this cross consisted of 4 females of the Beith Zera isolate, 3 males of the Misgav isolate and a further 3 males of the Aielet isolate (Wohlfarth et al, 1965). The base population thus consisted of a mixture 2 crossbreds, with a common female parent. Selection thresholds were determined from measurements of height and length carried out on a sample of 100 fish. Fish with a height/length ratio of $<0.365$ or $>0.420$ were defined as down selects and up selects, respectively (see fig 1). Selection involved measuring the height and length and computing the height/length ratio of $c a 1000$ fish. The 


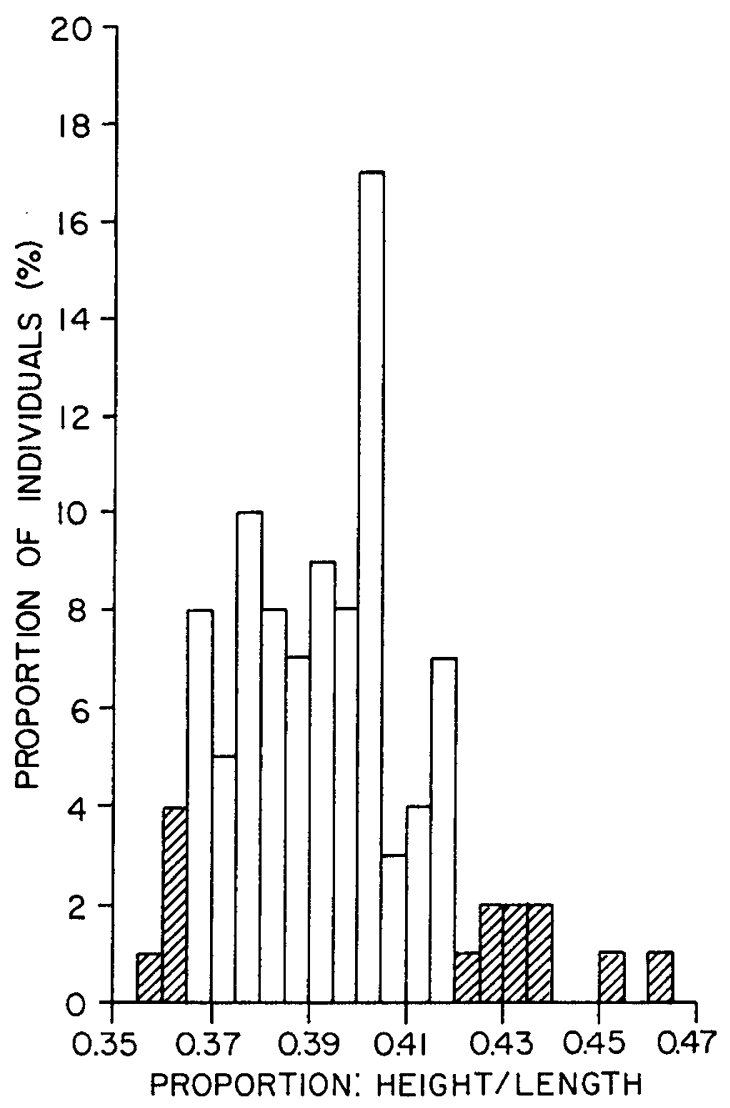

Fig 1. The frequency distribution of the ratio height/length (based on a sample of $100 \mathrm{fish}$ ). Shaded columns represent the selected samples.

experimental groups consisted of 33 up selects (3\%), 49 down selects (5\%); and 48 control fish, randomly taken prior to selection. During selection, the data on height and length were immediately converted to ratios, and used as selection criteria (up selects, down selects or rejection), and not noted. The 3 groups of fish were taken to the research station at Dor, differentially marked, separated into females and males and grown separately till the following spring. In April of the following year, 3 separate spawns were arranged by re-uniting the females and males of each group in a separate spawning pond. A random sample of fry from each spawning pond was transferred to a separate nursing pond. The nursed fingerlings were marked differentially, and stocked into 3 replicated communal testing ponds, situated in the fish farms Beit Zera, Nir David and Gan Shmuel. The methodology of genetic testing in communal ponds is described by Wohlfarth and Moav (1985). Several further genetic groups of common carp, stocked into these ponds, are regarded as part of the common environment and ignored in this presentation, since they are not connected with the height/length test groups. Ponds were stocked on July 8 . 
The test was terminated after about 4 months by draining the ponds, removing all the fish, and sorting them according to their group marks. The fish of each group were counted, weighed and the height and length of each was measured individually and noted. This enabled computing survival, growth, height, length and the height/length ratio of these 3 groups of fish. The realized heritability of relative height was estimated from the ratio of selection response to selection differential and the standard error of the estimate was calculated according to Hill (1971). The correlated response of the component traits (height and length) to selection for the height/length ratio was estimated from mean differences in these traits between selected and random samples.

\section{RESULTS}

The results of this test, carried out in 3 communal testing ponds are shown in table I. Previously these groups had been nursed in separate nursing ponds to a size sufficient for differential marking (Wohlfarth and Moav, 1985). This resulted in

Table I. a, Management characteristics in a bidirectional mass selection experiment for body shape in common carp: growth periods. b, Stocking and survival, weights and growth.

\begin{tabular}{lcccc}
\hline a & & Stocked & Harvest & Duration (d) \\
\hline \multirow{4}{*}{ Farm } & BZ & 8 Jul & 31 Oct & 115 \\
& ND & 8 Jul & 28 Oct & 112 \\
& GS & 8 Jul & 9 Nov & 124 \\
\hline
\end{tabular}

\begin{tabular}{llccccc}
\hline b & & $\begin{array}{c}\text { No stocked } \\
\text { (No fish) }\end{array}$ & Survival (\%) & \multicolumn{3}{c}{ Mean weight (g) } \\
& & & & fnitial & final & gain \\
\hline \multirow{4}{*}{ Control } & BZ & 59 & $103^{*}$ & 42 & 608 & 521 \\
& ND & 58 & 83 & 41 & 541 & 462 \\
& GS & 61 & 87 & 36 & 273 & 224 \\
& Mean & 59 & 91 & 40 & 474 & 399 \\
Up selects & BZ & 173 & 83 & 25 & 511 & 517 \\
& ND & 171 & 80 & 26 & 492 & 491 \\
& GS & 159 & 62 & 25 & 251 & 242 \\
& Mean & 168 & 75 & 25 & 418 & 416 \\
Down selects & BZ & 154 & 83 & 28 & 569 & 559 \\
& ND & 157 & 84 & 28 & 544 & 533 \\
& GS & 163 & 69 & 31 & 274 & 243 \\
& Mean & 158 & 79 & 29 & 462 & 441 \\
\hline
\end{tabular}

* Apparent survival $>100 \%$ presumably due to sorting error. ${ }^{* *}$ Observed weight gains corrected for differences in initial weight with the aid of the correction factor $b=4.543-0.113 X+0.00671 Y$. (Wohlfarth and Milstein, 1987). BZ: Beit Zera; ND: Nir David; GS: Gan Shmuel. 
random variation in mean weights among the test groups, that of the control being somewhat higher ( $40 \mathrm{~g}$ ) than those of the up and down select groups (25 and $29 \mathrm{~g}$ respectively). Survival of fish was between 75 and $90 \%$ with no significant differences between the groups. The apparent survival of $>100 \%$ in one case (control, Beith Zera), was probably a result of error in identifying fish at harvest. Mean harvest weights at Beith Zera and Nir David were close to market weight (of that time); that at Gan Shmuel was much lower.

\section{Correcting observed weight gains}

Observed weight gains (final weight - initial weight) of each group were corrected for the deviations of their initial weight, with the aid of a predicted correction factor computed separately for each pond (Wohlfarth and Milstein, 1987). The predicted correction factors were 4.49, 4.24 and 3.86 for the ponds at Beith Zera, Nir David and Gan Shmuel, respectively. Observed weight gains were corrected with the aid of the equation: $Y^{\prime}=Y-b(X-X$.$) , where Y^{\prime}$ and $Y=$ corrected and observed weight gains, respectively; $X$ and $X .=$ initial weight of a given genetic group and mean initial weight of all tested groups, respectively; and $b=$ the appropriate correction factor (Wohlfarth and Moav, 1985).

\section{Realized heritability}

The results of bidirectional selection for body shape are shown in figure 2 . In the parent generation, the selection differentials of the up select and down select groups deviated by 0.049 and 0.030 units respectively around the mean. In the progeny, a selection response was generated in both directions, in each of the 3 replications. Estimates of realized heritabilities are shown in table II. Up selection generated a larger response than down selection, similar to the higher selection differential of the up selection group. Estimates of realized heritability (selection response/selection differential) generated in this study were $0.47 \pm 0.06,0.33 \pm 0.10$ and $0.42 \pm 0.03$ for up selection, down selection and simultaneous bidirectional selection.

\section{Correlated response of height and length}

Data on height and length of progenies of up selects, down selects and controls are shown in table III. Selection for the height/length ratio generated a response in both height and length. For each sample and in each pond, fish of the up select line had an absolutely greater mean height and an absolutely smaller mean length than fish of the control group. The opposite is the case for fish of the down select line. A direct comparison between correlated responses of height and length requires standardization of the results, since mean length of the control group is close to 3 times as high as mean height. Standardization was carried out by dividing response by the absolute value of the control group, in each case (see relative response, last 2 columns in table III). These show that the correlated response of length is about 3.5 as high as that of height, and that the correlated response to up selection is about 2.5 as high as that to down selection. Realized heritabilities of height and length could not be estimated, since absolute data on height and length were not noted for the parent generation (see Materials and Methods). 


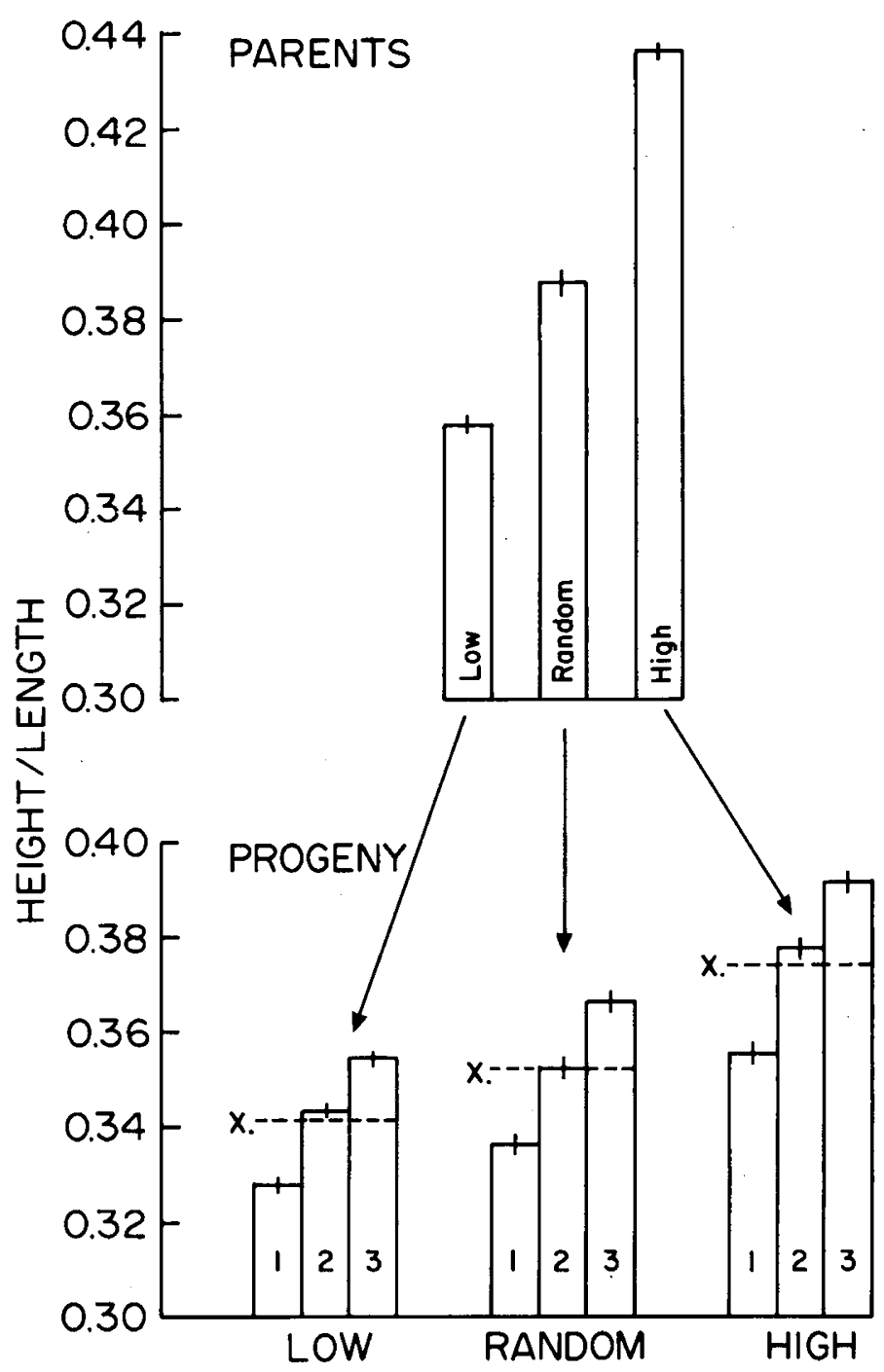

Fig 2. Bidirectional mass selection for body shape (height/length) in common carp. Short vertical lines show standard errors of the mean. Broken horizontal lines show means over three replications. 1, 2 and 3 represent replications in which progenies were tested at Gan Shmuel, Beith Zera and Nir David, respectively.

\section{Correlation between growth and body shape}

The relation between corrected weight gain and the ratio of height/length is shown in figure 3. In each replication (pond), the highest corrected weight gain was shown 
Table II. Estimating realized heritabilities for body shape (height/length).

\begin{tabular}{|c|c|c|c|c|c|c|c|}
\hline \multirow[t]{2}{*}{ Generation } & \multirow[t]{2}{*}{ Farm $^{*}$} & \multirow{2}{*}{ 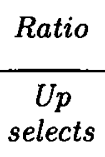 } & \multicolumn{2}{|c|}{ height/length } & \multicolumn{3}{|c|}{ Realized heritability } \\
\hline & & & Control & $\begin{array}{l}\text { Down } \\
\text { selects }\end{array}$ & $\begin{array}{c}\text { Up- } \\
\text { control }\end{array}$ & $\begin{array}{c}\text { Control- } \\
\text { down }\end{array}$ & $\begin{array}{c}U p- \\
\text { down }\end{array}$ \\
\hline Parents & & 0.437 & 0.388 & 0.358 & & & \\
\hline \multirow{4}{*}{ Progeny } & $\mathrm{BZ}$ & 0.378 & 0.353 & 0.344 & 0.51 & 0.30 & 0.43 \\
\hline & ND & 0.392 & 0.367 & 0.355 & 0.51 & 0.40 & 0.47 \\
\hline & GS & 0.356 & 0.337 & 0.328 & 0.39 & 0.30 & 0.35 \\
\hline & Mean & 0.375 & 0.352 & 0.342 & 0.47 & 0.33 & 0.42 \\
\hline
\end{tabular}

* See table I.

Table III. Mean absolute height and length (mm) of progenies of common carp selected for a high and low ratio of height/length and of their control group.

\begin{tabular}{|c|c|c|c|c|c|}
\hline \multirow[t]{3}{*}{ Farm $^{*}$} & \multicolumn{3}{|c|}{ Performance } & \multicolumn{2}{|c|}{ Relative response (\%) } \\
\hline & \multirow{2}{*}{$\begin{array}{c}\text { High } \\
\text { line } \\
(H)\end{array}$} & \multirow{2}{*}{$\begin{array}{l}\text { Control } \\
\text { line } \\
(C)\end{array}$} & \multirow{2}{*}{$\begin{array}{l}\text { Low } \\
\text { line } \\
(L)\end{array}$} & $H-C$ & $L-C$ \\
\hline & & & & $C$ & $C$ \\
\hline \multicolumn{6}{|c|}{ Height } \\
\hline $\mathrm{BZ}$ & 95.0 & 93.5 & 93.0 & 1.60 & -0.53 \\
\hline ND & 95.0 & 94.0 & 93.0 & 1.06 & -1.06 \\
\hline GS & 72.6 & 71.4 & 71.4 & 1.68 & 0.00 \\
\hline Mean & 87.5 & 86.3 & 85.8 & 1.43 & -0.58 \\
\hline \multicolumn{6}{|c|}{ Length } \\
\hline $\mathrm{BZ}$ & 251 & 265 & 269 & -5.28 & 1.51 \\
\hline ND & 242 & 257 & 261 & -5.84 & 1.56 \\
\hline GS & 204 & 212 & 218 & -3.77 & 2.83 \\
\hline Mean & 232.3 & 244.6 & 249.3 & -5.03 & 1.92 \\
\hline
\end{tabular}

* See table I.

by the down select line, ie the group with the lowest ratio of height/length, but no significant difference was shown among lines within replication.

\section{DISCUSSION}

\section{Heritability of the ratio height/length}

A single cycle of bidirectional selection generated a selection response in both directions. Estimates of realized heritability were 0.47 and 0.33 for up and down selection respectively. It is possible that these are overestimates. The population on which selection was practised consisted of 2 crossbreds, with a common female parent and 2 different male parents (see Materials and Methods). A difference in 


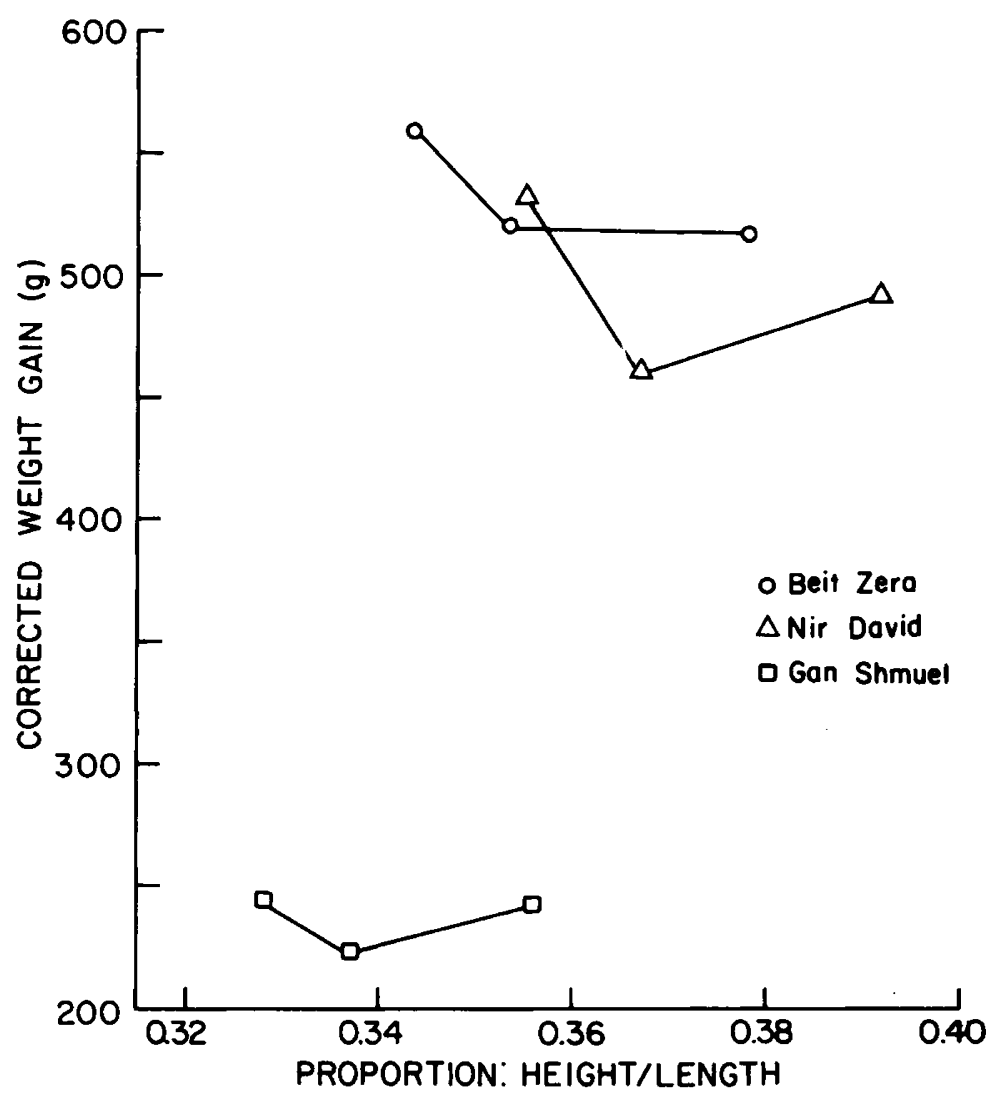

Fig 3. The association between growth (corrected weight gain) and body shape (height/length in 3 different ponds (replications).

the height/length ratio between the 2 crossbreds might have existed by chance. The up selects could therefore have included a high frequency of the crossbred with the higher height/length ratio, and similarly for the down selects, yielding higher heritabilities than expected within a single isolate. With such heritabilities, it appears possible to change the body shape of common carp fairly rapidly. Differences in body shape among different carp races and isolates are presumably due to differences in selection intensities and number of generations of selection practised in the past. Among our genetic stocks of common carp, a line introduced from Nasice in Yugoslavia possesses a particularly high ratio of height/length. This stock was subjected to several generations of mass selection for a high height/length ratio previous to its introduction to Israel (Moav et al, 1975). Similar selection was not carried out on our other stocks and these possess a much lower ratio of height/length.

The existence of environmental and genetic components of the trait height/length is evident from the results of this investigation. The environmental influence is 
seen by comparing the three replications. The lowest height/length ratio was found in Gan Shmuel, ie in the pond with the slowest growth and therefore the worst environment. The high estimates of realized heritability generated in this study indicate a strong additive genetic component in the total variation of the trait height/length.

\section{Response to selection, realized heritabilities, correlated responses}

The genetic response to bidirectional selection of the height/length ratio generated high estimates of realized heritabilities (between $0.47-0.35$; see table II). Up and down selections generated estimates of the same order of size. Correlated responses in the component traits (table III) are presumably a result of differences generated by selection for the height/length ratio. It is not possible to estimate and compare realized heritabilities of absolute height and absolute length in this investigation, since data of these absolute values were not noted (see Materials and Methods). This comparison is of interest when considering whether the height/length ratio is most effectively improved by direct selection for the ratio or by selection for the component traits.

\section{Selecting for a ratio between 2 traits}

Ratios between different traits, such as feed conversion ratio, proportion of body fat, egg mass/body weight, etc have served as selection goals in farm animals (beef cattle, broilers, etc) and laboratory animals (mice, flour beetles, etc). Selecting for improvements in ratios between 2 traits may be complicated by the disproportionate fashion in which selection pressure is exerted on component traits and their different response to selection. It is influenced by the phenotypic variability of the 2 traits, their heritabilities, and the correlation between numerator and denominator traits. Alternatives to selection for a ratio between 2 traits include selection for either numerator or denominator traits, or simultaneous selection for both traits, involving linear selection indices. Use of selection indices may be more effective in generating a selection response in a ratio than direct selection for that ratio, when the heritabilities of the 2 component traits are unequal and their phenotypic correlations low, and at high selection intensities (Gunsett, 1984). This was demonstrated in an investigation on selection for egg mass/adult weight ratio in Triboleum castaneum (Campo and Rodriguez, 1990). In a study on feed conversion ratio in beef cattle however, selection responses generated by direct selection for the ratio or selection by means of an index were similar (Davis, 1987). In our study, both height and length responded to mass selection (see table III), the relative response of length being larger than that of height. Since the selection differentials of these 2 traits were not estimated, it is not possible to estimate their heritabilities, or to compare them to the heritabilities of the height/length ratio. As a result, available data do not enable predicting whether selection for the ratio or for its component traits is more effective. 


\section{Association between body shape and growth}

The apparently negative association between the height/length ratio and growth is probably meaningless, since differences in growth among test groups were not significant. This negative correlation is however consistent with the results of a similar study among Polish carp (Stegman, 1968). In any case, there are no indications that growth rate may be improved indirectly by selecting the highest backed individuals.

\section{REFERENCES}

Ankorion Y (1966) Studies on the heredity of some morphological characteristics in the common carp (Cyprinus carpio L). M Sc thesis, Hebrew University, Jerusalem $66 \mathrm{p}$ (in Hebrew)

Anwand K (1961) Biometrische Untersuchungen an Karpfen aus der Teichwirtschaft Peitz. Z Fisch Hilfswiss 10 NF, 69-104

Campo JL, Rodriguez M (1990) Relative efficiency of selection methods to improve a ratio of two traits in Tribolium. Theor Appl Genet 80, 343-348

Davis ME (1987) Divergent selection for post-weaning feed conversion in beef cattle: predicted response based on an index of feed intake and gain $v s$ feed: gain ratio. $J$ Anim Sci 65, 886-895

Gunsett FC (1984) Linear index selection to improve traits defined as ratios. $J$ Anim Sci 59, 1185-1193

Hill WG (1971) Design and efficiency of selection experiments for estimating genetic parameters. Biometrics 27, 293-311

Hofmann J (1975) Der Teichwirt. Zucht und Haltung des Karpfens. Paul Parey, Hamburg, 4th edn, $312 \mathrm{p}$

Mann H (1961) Fish cultivation in Europe. In: Fish as Food (Bergstrom G, ed) Academic Press, New York, vol 1, 70-102

Moav R, Hulata G, Wohlfarth G (1975) Genetic differences between the Chinese and European races of the common carp 1. Analysis of genotype - environment interaction for growth rate. Heredity $34,323-340$

Stegman K (1968) The estimation of the quality of carp by means of length/height ratio and relative weight gains. FAO Fish Rep 44 (4), 160-168

Willer A (1933) Uber die Zuchtziele in der Karpfenteichwirtschaft. Mitteilungen der Deutschen Landwirtshaftsgesellschaft 10/11, 1-3

Wohlfarth G, Lahman M, Moav R, Ankorion Y (1965) Activities of the Carp Breeders Union in 1964. Bamidgeh 17, 9-15

Wohlfarth GW, Milstein A (1987) Predicting correction factors for differences in initial weight among genetic groups of common carp in communal testing. Aquaculture 60, 13-25

Wohlfarth GW, Moav R (1985) Communal testing, a method of testing the growth of different genetic groups of common carp in earthen ponds. Aquaculture 48, 143157 